\title{
Hubungan Tingkat Pengetahuan terhadap Penggunaan Obat Parasetamol Rasional dalam Swamedikasi
}

Irma Nurtiana Syafitri ${ }^{1}$, Ika Ratna Hidayati ${ }^{1}$, Liza Pristianty ${ }^{2}$

${ }^{1}$ Program Studi Farmasi, Fakultas Ilmu Kesehatan, Universitas Muhammadiyah Malang

${ }^{2}$ Program Studi Farmasi, Fakultas Farmasi, Universitas Airlangga, Surabaya

*Corresponding author: irmanurtiana@gmail.com

\begin{abstract}
Background: The most commonly-used medication for self-medication was paracetamol. Paracetamol was used to relieve mild or moderate pain and mild-feverish conditions. Objective: This study was to discover the correlation between levels of knowledge and the rational use of paracetamol in self-medication done by the students of the Health Science Department in University of Muhammadiyah Malang. Methods: This study was an observational analysis using cross sectional method in which the sampling method employed purposive sampling method, and the instrument for this study was in a form of questionnaires. The study indicated that the students' knowledge related to the rational use of paracetamol in self- medication was as follows good $70 \%$ (61 students), quite good 26\% (23 students), less good 4\% (3 students), and there was no student who fell to "not good" category. The students with positive action (using paracetamol rationally) were 53\% (46 students), while 47\% (41 students) of them are with negative action (using paracetamol irrationally). Results: The result showed that spearman correlation with value of $r$-count higher than $r$-table $(0.301>0.213)$ and significance value less than $\alpha=0.05(0.005<0.050)$ with correlation coefficient value $0.301(30 \%)$ indicated that the relationship between variables was low, but certainly existed. Conclusion: There was a correlation between the levels of knowledge and the rational use of paracetamol in self-medication practice in the students of Health Science Department at University of Muhammadiyah Malang.
\end{abstract}

Keyword: knowledge, behavior, action, self-medication, paracetamol

\begin{abstract}
Abstrak
Pendahuluan: Obat yang paling umum digunakan untuk pengobatan sendiri yaitu parasetamol. Parasetamol digunakan untuk menghilangkan nyeri ringan sedang dan kondisi demam ringan. Tujuan: Mengetahui hubungan tingkat pengetahuan dengan penggunaan obat parasetamol yang rasional dalam swamedikasi pada mahasiswa Kesehatan, Universitas Muhammadiyah Malang. Metode: Penelitian ini merupakan penelitian observasional analitik dengan pendekatan metode cross sectional dimana pengambilan sampel dilakukan dengan metode purposive sampling dan instrumen yang digunakan berupa kuisioner. Mahasiswa yang memiliki tingkat pengetahuan baik tentang obat parasetamol sebesar 70\% (61 orang), mahasiswa yang memiliki tingkat pengetahuan cukup tentang obat parasetamol sebesar $26 \%$ (23 orang), mahasiswa yang memiliki tingkat pengetahuan kurang tentang obat parasetamol sebesar $4 \%$ (3 orang) dan tidak ada mahasiswa yang berpengetahuan tidak baik. Mahasiswa dengan tindakan positif (penggunaan obat parasetamol rasional) sebesar 53\% (46 orang) dan mahasiswa dengan tindakan negatif (penggunaan obat parasetamol tidak rasional) sebesar 47\% (41 orang). Hasil: Hasil analisis korelasi spearman dengan nilai $r$ hitung lebih besar daripada nilai $r$ tabel $(0,301>0,213)$ dan nilai signifikan kurang dari $\alpha=0,05(0,005<0,050)$ dengan nilai koefisien korelasi 0,301 (30\%) menunjukkan bahwa hubungan antar variabel rendah. Kesimpulan: Terdapat hubungan antara tingkat pengetahuan terhadap penggunaan obat parasetamol rasional dalam swamedikasi pada mahasiswa Kesehatan, Universitas Muhammadiyah Malang.
\end{abstract}

Kata Kunci: pengetahuan, perilaku, tindakan, swamedikasi, parasetamol 


\section{PENDAHULUAN}

Menurut World Health Organization (WHO) swamedikasi merupakan pemilihan dan penggunaan obat, baik obat modern maupun obat tradisional yang digunakan oleh seseorang untuk melindungi diri dari penyakit dan gejala penyakit yang lain. (WHO, 1998).

Swamedikasi memberikan kontribusi yang sangat besar bagi pemeliharaan kesehatan, namun bila tidak dilakukan secara benar justru menimbulkan sesuatu yang tidak diinginkan yaitu tidak sembuhnya penyakit atau munculnya penyakit baru karena efek samping dari obat yang digunakan. Dalam melakukan swamedikasi yang aman, efektif dan terjangkau, masyarakat perlu memiliki bekal pengalaman dan keterampilan. Masyarakat mutlak memerlukan informasi yang jelas sumbernya dan terpercaya sehingga penentuan kebutuhan obat dapat diambil berdasarkan alasan yang rasional (Suryawati, 1997). Berdasarkan data dari Badan Pusat Statistik (BPS) (2014) tentang swamedikasi oleh penduduk di peroleh data dari tahun 2002 sampai dengan tahun 2014 untuk pengobatan modern sebesar $86,68 \%$; pengobatan tradisional $32,90 \%$ dan lain-lain $8,13 \%$. Hasil ini juga didukung oleh indikator kesehatan dari BPS yang mengatakan persentase penduduk yang mengobati sendiri sebesar 72,44\% dan Persentase penduduk yang berobat jalan (pergi ke dokter) sebesar 38,21\% pada tahun 2004. (Badan Pusat Statistik, 2016). Berdasarkan data tersebut membuktikan bahwa masyarakat sebagian besar lebih memilih untuk melakukan swamedikasi dibanding dengan berobat ke dokter.

Hasil penelitian Imtiaz, dkk. (2013) mengatakan bahwa dari 300 responden yang swamedikasi obat parasetamol menunjukkan persentase $83 \%$, NSAID $67 \%$, antibiotik $50 \%$, vitamin $60 \%$. Penelitian ini menunjukkan bahwa penggunaan obat parasetamol banyak digunakan.

Parasetamol (asetaminofen) merupakan obat bebas, obat dengan golongan ini termasuk obat yang relatif paling aman digunakan, karena dapat diperoleh tanpa resep dokter, selain di apotek dapat juga diperoleh di warung/toko terdekat dan pelayanan kesehatan lainnya. Obat bebas dalam kemasannya ditandai dengan lingkaran berwarna hijau (Depkes RI, 2007). Parasetamol digunakan untuk menghilangkan nyeri ringan sedang dan kondisi demam ringan. (Sweetman, 2009) Selain itu, parasetamol juga termasuk obat analgetik non narkotik yaitu memiliki cara kerja dengan menghambat sintesis prostaglandin terutama di Sistem Syaraf Pusat (SSP) (Darsono, 2002).
Pengetahuan berdasarkan konsep perilaku Lawrence Green (1980) ialah salah satu dari faktor predisposisi yang berpengaruh terhadap kesehatan seseorang. Pengetahuan/kognitif adalah domain yang sangat penting untuk terbentuknya tindakan seseorang (Notoatmodjo, 2010). Ada beberapa pengetahuan minimal terkait swamedikasi yang sebaiknya dipahami masyarakat, pengetahuan tersebut meliputi tentang mengenali gejala penyakit, memilih produk yang sesuai dengan indikasi dari penyakit, mengikuti petunjuk yang tertera pada etiket brosur obat, memantau hasil terapi dengan kemungkinan efek samping yang ada (Depkes RI, 2007).

Penelitian yang dilakukan oleh Febryery (2012) yaitu hubungan antara tingkat pengetahuan mahasiswa Farmasi di Universitas Muhammadiyah Surakarta terhadap tindakan swamedikasi, mendapatkan hasil katagori baik untuk pengetahuan yaitu sebesar $81 \%$, serta untuk tindakan swamedikasi dengan kategori baik sebesar $73 \%$.

Analisis kerasionalan penggunaan obat menurut Lestari (2014), dapat dilihat dari 4T yaitu tepat indikasi penyakit, tepat obat, tepat pasien dan tepat dosis obat.

Melihat gambaran dari tingkat pengetahuan dan besarnya swamedikasi, maka perlu dilakukannya penelitian mengenai hubungan tingkat pengetahuan terhadap penggunaan obat parasetamol rasional dalam swamedikasi, studi ini dilakukan pada mahasiswa Kesehatan, Universitas Muhammadiyah Malang.

Penelitian ini dilakukan ini dengan dengan latar belakang mahasiswa yang sudah mengerti obat dalam dunia kesehatan yaitu mahasiswa Kedokteran, Farmasi, Fisioterapi, dan Perawat. Berdasarkan pengetahuannya mahasiswa selama ini sudah terbiasa melakukan swamedikasi.

\section{METODE}

Penelitian ini merupakan penelitian observasional analitik yaitu dengan pendekatan metode cross sectional dimana data yang terkait variabel terikat dikumpulkan dalam waktu yang bersamaan (Notoatmodjo, 2005).

Penelitian ini menggunakan Teknik Sampling yaitu non-probability sampling (purposive sampling). Populasi dalam penelitian ini adalah semua mahasiswa Kesehatan, Universitas Muhammadiyah Malang (yang meliputi mahasiswa Kedokteran, Farmasi, Perawat, dan Fisioterapi). Sampel yang didapat adalah 87 mahasiswa yang menggunakan obat parasetamol secara swamedikasi dan memenuhi kriteria inklusi yang telah ditentukan. Kriteria inklusi pada penelitian ini yaitu : 
1. Mahasiswa/i yang menggunakan obat yang mengandung parasetamol untuk swamedikasi dengan dosis 325 - $650 \mathrm{mg}$ sekali minum.

2. Mahasiswa/i yang pernah menggunakan obat yang mengandung parasetamol maksimal 1 bulan terakhir penggunaannya.

3. Mahasiwa/i kesehatan yang bersedia menjadi responden dan mengisi informed consent (Mahasiswa/i Universitas Muhammadiyah Malang angkatan 2013).

Lokasi dari penelitian ini adalah di kampus 2 Universitas Muhammadiyah Malang dan Rumah Sakit Pendidikan Universitas Muhammadiyah Malang. Waktu penelitian dilaksanakan pada bulan Januari Februari 2017.

Variabel Penelitian pada penelitian ini terdapat dua variabel yang akan diteliti, yaitu variabel bebas dan variabel terikat.

Variabel bebas dalam penelitian ini adalah tingkat pengetahuan mahasiswa kesehatan dalam swamedikasi obat parasetamol. Tingkat pengetahuan disini mencakup seberapa jauh mahasiswa mengetahui mengenai Tepat Dosis (Tepat Jumlah, Tepat Cara Pemberian, Tepat Interval Waktu Pemberian, Tepat Lama Pemberian), Efek Samping, Penyimpanan, Tepat
Tindak Lanjut. Kategori penilaian yaitu: Baik (76\% $100 \%)$, cukup baik (56\% - 75\%), kurang baik (40\% $55 \%)$, dan tidak baik $(<40 \%)$.

Variabel terikat dalam penelitian ini adalah penggunaan obat parasetamol rasional dalam swamedikasi pada mahasiswa kesehatan. Penggunaan obat disini berarti mahasiswa telah melakukan tindakan penggunaan obat parasetamol sehingga dapat dilihat perilaku mahasiswa dalam meminum obat parasetamol dari cara penggunaan obat yang meliputi Tepat Indikasi Penyakit, Tepat Dosis (Tepat Jumlah, Tepat Cara Pemberian, Tepat Interval Waktu Pemberian, Tepat Lama Pemberian), Penyimpanan, Tepat Tindak Lanjut, Sehingga diperoleh dua kategori yaitu: Tindakan positif dan Tindakan negatif.

Instrumen Penelitian yang digunakan dalam penelitian ini adalah kuesioner tertutup tentang pengetahuan dan kuesioner tindakan yang menggunakan skala Likert, dengan alasan akuratisasi data dalam penelitian. Instrumen tersebut dilakukan uji validitas dan reliabilitas sebelum disebar pada responden penelitian. Kisi-kisi instrumen yang akan dilakukan pada penelitian ini dapat dilihat pada Tabel 1 dan untuk defenisi operasional variabel dapat dilihat dalam Tabel 2.

Tabel 1. Kisi-Kisi Instrumen

\begin{tabular}{llc}
\hline \multicolumn{1}{c}{ Variabel Penelitian } & \multicolumn{1}{c}{ Indikator } & No.item \\
\hline Tingkat pengetahuan mahasiswa & 1. Indikasi Penyakit & $2,3,4,5$ \\
dalam swamedikasi obat & 2. Tepat Dosis & \\
Parasetamol & a) Tepat Jumlah & \\
& b) Tepat Cara Pemberian & \\
& c) Tepat Interval Waktu Pemberian & 6 \\
& d) Tepat Lama Pemberian & 7 \\
& 3. Efek Samping & 8 \\
\hline Penggunaan obat parasetamol & 4. Penyimpanan & 1 \\
rasional dalam swamedikasi pada & 5. Tepat Tindak Lanjut & $2,3,4,5$ \\
mahasiswa & 1. Tepat Indikasi Penyakit & \\
& 2. Tepat Dosis & \\
& a) Tepat Jumlah & \\
& b) Tepat Cara Pemberian & \\
& c) Tepat Interval Waktu Pemberian & 6,7 \\
\hline
\end{tabular}


Tabel 2. Definisi Operasional Variabel

\begin{tabular}{|c|c|c|c|}
\hline Variabel & Defenisi Operasional & $\begin{array}{c}\text { Skala Data dan } \\
\text { Alat Ukur }\end{array}$ & Kategori \\
\hline $\begin{array}{l}\text { Tingkat pengetahuan } \\
\text { mahasiswa dalam } \\
\text { swamedikasi obat } \\
\text { Parasetamol }\end{array}$ & $\begin{array}{l}\text { Tingkat pengetahuan } \\
\text { mahasiswa tentang } \\
\text { swamedikasi obat } \\
\text { Parasetamol yang } \\
\text { mencangkup : } \\
\text { 1. Indikasi Penyakit } \\
\text { 2. Tepat Dosis } \\
\text { a) Tepat Jumlah } \\
\text { b) Tepat Cara } \\
\text { Pemberian } \\
\text { c) Tepat Interval } \\
\text { Waktu Pemberian } \\
\text { d) Tepat Lama } \\
\text { Pemberian } \\
\text { 3. Efek Samping } \\
\text { 4. Penyimpanan } \\
\text { 5. Tepat Tindak Lanjut }\end{array}$ & $\begin{array}{l}\text { Skala data : Ordinal } \\
\text { (skala peringkat) } \\
\text { Alat ukur: } \\
\text { Kuesioner tingkat } \\
\text { pengetahuan dengan } \\
\text { pernyataan ya atau tidak }\end{array}$ & $\begin{array}{l}\text { Dilakukan penilaian terhadap } \\
\text { kuesioner. Hasil yang diperoleh } \\
\text { dikelompokkan menjadi } 4 \text { kategori: } \\
\text { 1. Baik } 76-100 \% \\
\text { 2. Cukup } 56-75 \% \\
\text { 3. Kurang } 40-55 \% \\
\text { 4. Tidak Baik }<40 \%\end{array}$ \\
\hline $\begin{array}{l}\text { Penggunaan obat } \\
\text { parasetamol rasional } \\
\text { dalam swamedikasi } \\
\text { pada mahasiswa }\end{array}$ & $\begin{array}{l}\text { Penggunaan obat } \\
\text { parasetamol rasional } \\
\text { dalam swamedikasi } \\
\text { pada mahasiswa dengan } \\
\text { indikator berikut: } \\
\text { 1. Tepat Indikasi } \\
\text { Penyakit } \\
\text { 2. Tepat Dosis } \\
\text { a) Tepat Jumlah } \\
\text { b) Tepat Cara } \\
\text { Pemberian } \\
\text { c) Tepat Interval } \\
\text { Waktu Pemberian } \\
\text { d) Tepat Lama } \\
\text { Pemberian } \\
\text { 3. Penyimpanan } \\
\text { 4. Tepat Tindak Lanjut }\end{array}$ & $\begin{array}{l}\text { Skala data : Nominal } \\
\text { (skala label) } \\
\text { Alat ukur: } \\
\text { Kuesioner Penggunaan } \\
\text { obat parasetamol } \\
\text { rasional/Tindakan } \\
\text { dengan skala likert }\end{array}$ & $\begin{array}{l}\text { Dilakukan penilaian terhadap } \\
\text { kuesioner. Hasil yang diperoleh } \\
\text { dikelompokkan menjadi } 2 \text { kategori: } \\
\text { 1. Tindakan positif bila skor } \\
\quad-\mathrm{T} \geq \text { mean } \mathrm{T} \text { kelompok. } \\
\text { 2. Tindakan negatif bila skor } \\
\quad-\mathrm{T} \leq \text { mean T kelompok. }\end{array}$ \\
\hline
\end{tabular}

\section{Pengumpulan data}

Data primer dalam penelitian ini digunakan kuesioner, dimana kuesioner menggunakan pertanyaan tertutup, secara tertulis dan sebelum melakukan pengumpulan data peneliti meminta persetujuan responden (informed consent) kemudian dilanjutkan dengan pengisian kuesioner.

\section{Uji validitas dan reliabilitas}

Uji validitas menggunakan rumus Pearson Product Moment (Arikunto, 2006). Berikut merupakan rumus Pearson Product Moment tersebut.

$$
r_{x y}=\frac{n \sum x y-\left(\sum x\right)\left(\sum y\right)}{\sqrt{\left\{n \sum \sum_{x} 2-\left(\sum x\right)^{2}\right\}\left\{n \sum_{y} 2-\left(\sum y\right)^{2}\right\}}}
$$

Keterangan :

$\mathrm{r}_{\mathrm{xy}}=$ indeks korelasi antara dua belahan instrumen

$\mathrm{n} \quad=$ jumlah butir pertanyaan

$\sum \mathrm{x}=$ jumlah skor pada belah ganjil

$\sum \mathrm{y}=$ jumlah skor pada belah genap

Dari analisis rumus diatas, dapat diketahui jika:

1. Bila $r$ xy hitung $<\mathrm{r}$ tabel maka kuesioner tersebut tidak valid.

2. Bila $\mathrm{r}$ xy hitung $>\mathrm{r}$ tabel maka kuesioner tersebut valid. 
Uji reliabilitas membutuhkan 30 responden untuk mencapai kurva normal. Uji reliabilitas yang digunakan dalam penelitian ini menggunakan rumus Alpha Cronbach. Instrument dinyatakan reliabel bila nilai $\alpha>0,06$ atau sama dengan 1 (Sugiyono, 2009). Berikut merupakan rumus Alpha Cronbach.

$$
r_{11}=\left[\frac{k}{k-1}\right]\left[1-\frac{\sum \sigma i^{2}}{\sigma t^{2}}\right]
$$

Keterangan :

$\mathrm{r}=$ reliabilitas instrument

$\mathrm{k}$ = banyaknya item yang ditanyakan/banyaknya pertanyaan

$\sum \sigma i^{2}=$ jumlah varian butir atau item

$\sigma t^{2}=$ varian total

Menurut Tirton (2006), tingkat reliabelitas dengan metode Alpha Cronbach diukur berdasarkan skala Alpha 0 sampai 1, apabila skala tersebut dikelompokkan kedalam lima kelas dengan range yang sama, maka urutan kemantapan Alpha dapat diinterpretasikan pada Tabel 3.

Tabel 3. Tingkat Reliabilitas Berdasarkan Nilai Alpha (Triton, 2006)

\begin{tabular}{cc}
\hline Alpha & Tingkat Reliabilitas \\
\hline $0.0-0.20$ & Kurang Reliabel \\
$>0.20-0.40$ & Agak Reliabel \\
$>0.40-0.60$ & Cukup Reliabel \\
$>0.60-0.80$ & Reliabel \\
$>0.80-1.00$ & Sangat Reliabel \\
\hline
\end{tabular}

\section{Penilaian tingkat pengetahuan}

Setiap satu item pertanyaan yang dijawab benar diberi skor 1 dan jika jawaban salah diberi skor 0 , kemudian dimasukkan ke dalam rumus :

$$
P=\frac{F}{n} \times 100 \%
$$

Keterangan :

$\mathrm{P}=$ Nilai Persentase

$\mathrm{F}=$ Jawaban Benar

$\mathrm{n}=$ Jumlah soal

\section{Penilaian tindakan (penggunaan obat parasetamol} rasional)

Setiap item pertanyaan yang dijawab diberi skor mulai dari 1 sampai 4. Jumlah nilai kemudian dimasukkan ke dalam skala model Likert :

$$
\mathrm{T}=50+10\left[\frac{X-\bar{X}}{s}\right]
$$

Keterangan :

$\mathrm{X}$ : skor responden pada skala sikap yang akan diubah menjadi skor $\mathrm{T}$

$\overline{\mathrm{X}}$ : mean skor kelompok

$\mathrm{s}:$ standar deviasi kelompok

\section{Analisa data}

Setelah data diolah, maka data akan dianalisa dengan metode spearman test $(\alpha=0.05)$ dengan menggunakan bantuan program Statistical Product for Service Solution (SPSS) ver. 18 for Windows. Hasil data yang akan dianalisa dengan metode spearman dengan menggunakan program komputer SPSS (Statistical Product Service Solution) ver.18 dengan interval kepercayaan $95 \%$. Berikut merupakan rumusan hipotesa yang digunakan.

$\mathrm{H}_{0}=$ Tidak ada hubungan tingkat pengetahuan terhadap penggunaan obat parasetamol rasional dalam swamedikasi pada mahasiswa Kesehatan, Universitas Muhammadiyah Malang.

$\mathrm{H}_{1}=$ Ada hubungan tingkat pengetahuan terhadap penggunaan obat parasetamol rasional dalam swamedikasi pada mahasiswa Kesehatan, Universitas Muhammadiyah Malang.

Dari hasil analisa data diatas dapat diketahui jika:

1 Jika sig > 0,05 maka $\mathrm{H}_{0}$ diterima sedang $\mathrm{H}_{1}$ ditolak, artinya tidak ada hubungan tingkat pengetahuan terhadap penggunaan obat parasetamol rasional dalam swamedikasi.

2 Jika sig $<0,05$ maka $\mathrm{H}_{0}$ ditolak sedang $\mathrm{H}_{1}$ diterima, artinya ada hubungan tingkat pengetahuan terhadap penggunaan obat parasetamol rasional dalam swamedikasi

Hasil analisis akan diperoleh nilai koefisien korelasi. Koefisien korelasi ialah pengukuran statistik kovarian atau asosiasi antara dua variabel. Koefisien korelasi menunjukkan kekuatan (strength) hubungan linear dan arah hubungan dua variabel acak. Secara umum koefisien korelasi dilambangkan dengan " $\mathrm{r}$ ". Untuk menentukan keeratan hubungan atau korelasi antar variabel, maka diberikan nilai-nilai dari koefisien korelasi (r) pada Tabel 4 (Hasan, 2006). 
Tabel 4. Interval Nilai Koefisien Korelasi dan Kekuatan Hubungan (Hasan, 2006)

\begin{tabular}{|c|c|c|}
\hline No. & Interval Nilai & Kekuatan Hubungan \\
\hline 1. & $|\mathrm{r}|=0$ & Tidak terdapat korelasi \\
\hline 2. & $0,00<|\mathrm{r}| \leq 0,20$ & $\begin{array}{l}\text { Sangat rendah atau } \\
\text { lemah sekali }\end{array}$ \\
\hline 3. & $0,20<|\mathrm{r}| \leq 0,40$ & $\begin{array}{l}\text { Rendah atau lemah tapi } \\
\text { pasti }\end{array}$ \\
\hline 4. & $0,40<|r| \leq 0,70$ & $\begin{array}{l}\text { Cukup berarti atau } \\
\text { sedang }\end{array}$ \\
\hline 5. & $0,70<|r| \leq 0,90$ & Tinggi atau kuat \\
\hline 6. & $0,90<|\mathrm{r}| \leq 0,100$ & $\begin{array}{c}\text { Sangat tinggi atau kuat } \\
\text { sekali }\end{array}$ \\
\hline 7. & $|r|=1,00$ & Sempurna \\
\hline
\end{tabular}

\section{HASIL DAN PEMBAHASAN}

\section{Kategori tingkat pengetahuan obat parasetamol} rasional dalam swamedikasi

Berdasarkan Tabel 5 mahasiswa yang pengetahuannya Baik sebanyak 61 orang $(70 \%)$, mahasiswa yang pengetahuannya Cukup sebanyak 23 orang (26\%), mahasiswa dengan pengetahuan Kurang sebanyak 3 orang (3\%), dan mahasiswa dengan pengetahuan Tidak Baik tidak ada $(0 \%)$.

Tabel 5. Kategori Tingkat Pengetahuan obat parasetamol rasional dalam swamedikasi

\begin{tabular}{ccc}
\hline Pengetahuan & $\begin{array}{c}\text { Frekuensi } \\
\text { (orang) }\end{array}$ & Persentase (\%) \\
\hline Baik & 61 & $70 \%$ \\
Cukup & 23 & $26 \%$ \\
Kurang & 3 & $3 \%$ \\
Tidak Baik & 0 & $0 \%$ \\
Total & 87 & $100 \%$ \\
\hline
\end{tabular}

Kategori tindakan (penggunaan obat parasetamol rasional)

Berdasarkan Tabel 6 mahasiswa dengan tindakan positif (Penggunaan Obat Parasetamol Rasional) sebanyak 46 orang $(53 \%)$ dan mahasiswa dengan tindakan negatif (Penggunaan Obat Parasetamol tidak Rasional) sebanyak 41 orang (47\%).

Tabel 6. Kategori Tindakan (Penggunaan Obat

\begin{tabular}{ccc}
\multicolumn{3}{c}{ Parasetamol Rasional) } \\
\hline Tindakan & $\begin{array}{c}\text { Frekuensi } \\
\text { (orang) }\end{array}$ & Persentase (\%) \\
\hline Positif & 46 & $53 \%$ \\
Negatif & 41 & $47 \%$ \\
Total & 87 & $100 \%$ \\
\hline
\end{tabular}

\section{Uji korelasi spearman}

Hasil uji Spearman hubungan tingkat pengetahuan terhadap penggunaan obat parasetamol rasional dalam swamedikasi pada mahasiswa Kesehatan, Universitas Muhammadiyah Malang dapat dilihat di Tabel 7.

Tabel 7. Hasil Uji Korelasi Spearman

\begin{tabular}{cccc}
\hline \multirow{2}{*}{ hitung } & Sig & $\begin{array}{c}r \text { tabel } \\
(\mathrm{df}=85, \\
\alpha=0,05)\end{array}$ & Keputusan \\
\hline 0,301 & 0,005 & 0,213 & H1 Diterima \\
\hline
\end{tabular}

Nilai $r$ hitung yang di dapat lebih besar daripada nilai $r$ tabel yaitu $0,301>0,213$, dan selain itu nilai signifikansi kurang dari $\alpha=0,05(0,005<0,050)$ sehingga dapat dinyatakan bahwa $\mathrm{H}_{1}$ diterima. Berdasarkan pengujian ini dapat dinyatakan bahwa ada hubungan tingkat pengetahuan terhadap penggunaan obat parasetamol rasional dalam swamedikasi pada mahasiswa Kesehatan, Universitas Muhammadiyah Malang. Koefisien korelasi positif mengindikasikan bahwa terdapat hubungan yang positif antara tingkat pengetahuan dengan perilaku swamedikasi obat. Dengan kata lain, semakin baik pengetahuan mahasiswa tentang swamedikasi obat parasetamol maka semakin positif tindakan atau penggunaan obat parasetamol rasional dalam swamedikasi pada mahasiswa Kesehatan, Universitas Muhammadiyah Malang.

\section{Analisa data crostabs}

Hasil analisis SPSS ver. 18 for Windows dengan Crosstabs untuk penyajian data tingkat pengetahuan dan tindakan (penggunaan obat parasetamol rasional) dalam swamedikasi pada Mahasiswa Kesehatan, Universitas Muhammadiyah Malang dapat dilihat di Tabel 8. 
Tabel 8. Crosstabs Tingkat Pengetahuan dan Tindakan

\begin{tabular}{ccccc}
\hline \multirow{2}{*}{ Pengetahuan } & \multicolumn{3}{c}{ Tindakan } & \multirow{2}{*}{ Total } \\
& & positif & negatif & \\
\hline \multirow{2}{*}{ baik } & Jumlah & 38 & 23 & 61 \\
& $\%$ Total & $43.7 \%$ & $26.4 \%$ & $70.1 \%$ \\
\hline \multirow{2}{*}{ cukup } & Jumlah & 8 & 15 & 23 \\
& $\%$ Total & $9.2 \%$ & $17.2 \%$ & $26.4 \%$ \\
\hline \multirow{2}{*}{ kurang } & Jumlah & 0 & 3 & 3 \\
& $\%$ Total & $.0 \%$ & $3.4 \%$ & $3.4 \%$ \\
\hline \multirow{2}{*}{ Total } & Jumlah & 46 & 41 & 87 \\
& $\%$ Total & $52.9 \%$ & $47.1 \%$ & $100.0 \%$ \\
\hline
\end{tabular}

Berdasarkan Tabel 8 diketahui bahwa mahasiswa dengan pengetahuan baik sebanyak 61 orang (38 orang dengan tindakan positif dan 23 orang dengan tindakan negatif pada penggunaan obat parasetamol rasional dalam swamedikasi), mahasiswa dengan pengetahuan cukup sebanyak 23 orang (8 orang dengan tindakan positif dan 15 orang dengan tindakan negatif pada penggunaan obat parasetamol rasional dalam swamedikasi), dan mahasiswa dengan pengetahuan kurang sebanyak 3 orang (3 orang dengan tindakan negatif dan tidak ada mahasiswa dengan tindakan yang positif pada penggunaan obat parasetamol rasional dalam swamedikasi). Jadi total mahasiswa dengan tindakan positif pada penggunaan obat parasetamol dalam swamedikasi sebanyak 46 orang dan mahasiswa dengan tindakan negatif pada penggunaan obat parasetamol dalam swamedikasi sebanyak 41 orang.

\section{KESIMPULAN}

Berdasarkan data dari hasil penelitian yang telah dilakukan oleh penulis dapat disimpulkan bahwa :

1. Mahasiswa yang memiliki tingkat pengetahuan baik tentang obat parasetamol sebesar $70 \%$ (61 orang), Mahasiswa yang memiliki tingkat pengetahuan cukup tentang obat parasetamol sebesar 26\% (23 orang), Mahasiswa yang memiliki tingkat pengetahuan kurang tentang obat parasetamol sebesar 4\% (3 orang) dan tidak ada mahasiswa yang berpengetahuan tidak baik.

2. Mahasiswa dengan tindakan positif (penggunaan obat parasetamol rasional) sebesar 53\% (46 orang) dan mahasiswa dengan tindakan negatif (penggunaan obat parasetamol tidak rasional) sebesar $47 \%$ (41 orang).

3. Terdapat hubungan antara tingkat pengetahuan terhadap penggunaan obat parasetamol rasional dalam swamedikasi pada mahasiswa Kesehatan, Universitas Muhammadiyah Malang. Hasil analisis korelasi spearman dengan nilai $r$ hitung lebih besar daripada nilai $r$ tabel $(0,301>0,213)$ dan nilai signifikan kurang dari $\alpha=0,05$ $(0,005<0,050)$. Nilai koefisien korelasi 0,301 (30\%) menunjukkan bahwa hubungan antar variabel rendah.

\section{DAFTAR PUSTAKA}

Arikunto, S. 2006. Prosedur Penelitian Suatu Pendekatan Praktek, Edisi VI. Jakarta: PT Rineka Cipta.

Badan Pusat Statistik. (2014). Persentase Penduduk yang Mengobati Sendiri Selama Sebulan Terakhir Menurut Provinsi dan Jenis Obat yang Digunakan, 2000-2014

http:/www.bps.go.id/. Accessed: 24 April 2016.

Badan Pusat Statistik. (2015). Indikator kesehatan 1995-2015.

http://www.bps.go.id/. Accessed: 24 April 2016.

Darsono, L. (2002). Diagnosis dan Terapi Intoksikasi Salisilat dan Parasetamol. Jurnal Kedokteran Maranatha; 2; 30-38.

Departemen Kesehatan RI (Depkes RI). (2007). Pedoman Penggunaan Obat Bebas dan Bebas Terbatas. Jakarta: Departemen Kesehatan RI.

Febryery, L. C. (2012). Evaluasi Hubungan Tingkat Pengetahuan Mahasiswa Farmasi Universitas Muhammadiyah Surakarta terhadap Tindakan Swamedikasi Acne Vulgaris. Skripsi; Fakultas Farmasi Universitas Muhammadiyah, Surakarta.

Hasan, Iqbal. (2006). Analisis Data Penelitian dengan Statistik. Jakarta: Bumi Aksara.

Imtiaz, S., Salam, N. A., Kamran. (2013). Conditions, Frequencies, and Sociodemographic Factors Leading Self Medication Practice in Sargodha Area of Punjab Pakistan. Journal of Applied Pharmaceutical Science; 5; 819-826.

Lestari, Y. P. (2014). Swamedikasi Penyakit Maag pada mahasiswa Bidang Kesehatan di Universitas Muhammadiyah Surakarta. Skripsi; Fakultas Farmasi Universitas Muhammadiyah, Surakarta.

Notoatmodjo, S. (2005). Metodelogi Penelitian Kesehatan. Jakarta: Rineka Cipta.

Notoatmodjo, S. (2010). Ilmu Perilaku Kesehatan. Jakarta: Rineka Cipta.

Sugiyono. (2009). Metode Penelitian Kuantitatif Kualitatif dan R\&D. Bandung: CV Alfabeta.

Suryawati, S. (1997). Menuju Swamedikasi yang Rasional. Jogjakarta: Pusat Studi Farmakologi Klinik dan Kebijakan Obat Universitas Gadjah Mada. 
Sweetman, S. C. (2009). Martindale the Complete Drug Reference $36^{\text {th }}$ ed. London: Pharmaceutical Press.
Triton, B. P. (2006). SPSS 1.3.0 Terapan; Riset Statistik Parametrik. Yogyakarta: CV Andi Offset.

WHO. (1998). The Role of the Pharmacist in Self-Care and Self-Medication. Netherlands: WHO. 